\title{
Persimmon farmer sees promise of regional marketing
}

Jim Bathgate well remembers the cold winter nights of his childhood in orange and avocado orchards lighting smudge pots to protect the fruit from frost. And he remembers the good years with equal dismay.

"When you had a good crop, everybody had a good crop," Bathgate says. "I saw times when avocados and oranges went for almost nothing, a few pennies a pound."

Meanwhile the persimmon trees on the family farm grew beautifully through the balmy Orange County summer and sold well each fall, primarily to Asian immigrants. Bathgate never forgot the ease with which they produced and sold the unusual, but remarkably luscious fruit.

When in 1975 he finally bought his own farm in San Diego County's Valley Center, Bathgate planted 1,000 Fuyu persimmon trees. Early on, growers couldn't produce enough persimmons to supply the growing ethnic market. However, other farmers jumped in, and soon the market was flooded.

It was then Bathgate began a quest to acquaint mainstream consumers with what he considers a gourmet taste. Fuyu persimmons are sweet and have the texture of a crispy apple when freshly picked. They can be softened on the countertop to the texture of mangoes or nectarines. Their mild flavor, Bathgate says, blends well in fruit salads and other dishes.

Bathgate developed a school curriculum on persimmons for the Farm Bureau Federation's $\mathrm{Ag}$ in the Classroom program.

"We have a fairly extensive lesson plan for elementary school teachers," Bathgate says. "We give it to local teachers with a box of fruit free of charge."

The package comes with a questionnaire for each child to take home with a persimmon. The student then has each member of the family taste and evaluate the fruit.

"It's just a way of getting the persimmons in new mouths," Bathgate says. "I've worked farmers' markets and have been almost belligerent forcing people to try it. But some people won't try anything new."

Bathgate tried to unite persimmon growers and launch a cooperative marketing effort, but couldn't drum up enough interest. With the UC Small Farm Program taking the lead on a new regional public relations and marketing effort, Bathgate says he has new hope.

"This program goes beyond individual crops," says Small Farm Program farm advisor Ramiro Lobo. "By creating an awareness of San Diego County's agricultural industry, and improving industry marketing, we will help all local farmers."

A public relations steering committee composed of farmers, tourism officials, UC Cooperative Extension staff and farm bureau representatives has met five times with consultant Michael Dimock, who is paid with funds from a $\$ 200,000$ grant the UC Small Farm Center received in 1998 from USDA's Fund for Rural America. Dimock has worked with a number of Northern California counties to develop their agricultural "brands," which include "Lake County Farmers' Finest," "Pride of Siskiyou," and "Humboldt Harvest."

"The San Diego program will have three elements: regional branding, agritourism and public education," Dimmock says. "All three elements will be designed to give local agriculture a more competitive edge."

Although implementation of the marketing campaign in San Diego County is a year or two away, the new possibilities for persimmon marketing are already beginning to surface.

"If we create gift packs with San Diego produce for sale at airports or other shops, we could include persimmons," Dimock says. "A persimmon farmer could be on a local farm tour map and sell his fruit directly to visitors."

While an individual producer might have difficulty making a dent in the San Diego marketplace, the steering committee assembled by the UC Small Farm Program has created a partnership with the power to successfully promote local farm products to the large local and tourism markets.
UC small farms advisor Ramiro Lobo and persimmon grower Jim Bathgate are working together to promote San Diego County agriculture. 